\title{
The readability of integrated reports
}

\author{
E. du Toit \\ Designation: Senior lecturer \\ Address: Department of Financial Management, University of Pretoria, Pretoria, South Africa \\ Email: elda.dutoit@up.ac.za
}

Tel: 0027124203818

\begin{abstract}
Purpose - This is an exploratory study to investigate the readability of integrated reports. The aim is to assess whether integrated reports are accessible to their readership and add value to stakeholders.

Design/methodology/approach - Readability analyses are performed on the integrated reports of all companies listed on the Johannesburg Stock Exchange for 2015 and 2016. Readability results are compared by means of a correlation analysis to the results of the Ernst \& Young Excellence in Integrated Reporting Awards for 2015.

Findings - The results show that the complex nature of the language used in integrated reports of listed companies impairs readability and, as an implication, affects the value stakeholders can derive from the information. The results from the correlation with the Ernst \& Young Excellence in Integrated Reporting Awards indicate that an integrated report is considered of higher quality if it is written using complex language.
\end{abstract}

Research limitations/implications - The main limitation of the study lies in its exclusively South African setting, which is the only country where integrated reports are recommended as part of stock exchange listings requirements. Another limitation is the fact that integrated reports are mainly aimed at informed users and is thus compiled with the informed reader in mind, which impacts on general readability.

Practical implications - The results present new findings regarding integrated reporting practice, which is of interest to firms, investors, regulators, amongst others. The findings show how the value-added by integrated reports could be improved.

Originality/value - This study is the first to investigate the readability of integrated reports in a South African context. The results indicate that integrated reports are difficult to read and are only useful to a portion of the total intended population. 


\section{Key words}

impression management, integrated reporting, organisational legitimacy, readability, understandability

\section{JEL Code}

M41

\section{Introduction}

"IIntegrated r]eporting matters. When done right, [integrated] reporting gives stakeholders a window through which to view the heart and soul of a company. [Integrated r]eporting provides insight into how a company views itself and its role in society. It communicates a company's performance, both good and bad. It creates commitments to improve in the future, both through specific targets and in response to the feedback a company gets from all of its stakeholders based on the information it makes available to them." (Krzus, 2011a, p. 82)

The purpose of an integrated report is to communicate in a concise way how a company's strategy, governance, performance, and prospects - in the context of its external environment create and sustain value (IIRC, 2013; IRCSA, 2011). Most companies listed on the Johannesburg Stock Exchange (JSE) prepare an integrated report, making South Africa the current world leader in integrated reporting practice. There seems to be a misconception that integrated reports are mandated by the JSE. This is, however, not the case. A guidance letter on integrated reporting was released in 2013 to clarify this (JSE, 2013) and explains that, since only some principles of the King Code on Corporate Governance are mandatory, the remainder can be adopted on an 'apply or explain' basis. Chapter 9 of King III, which deals with integrated reporting, is not a mandatory principle, therefore integrated reporting can be applied on an 'apply or explain' basis. However, this practice will change after the implementation of King IV, effective from 1 April 2017 (IoDSA, 2016). There are various reasons why most JSE listed companies present an integrated report, even if not mandatory. Research has shown that companies with more non-financial information disclosure outperform their peers (Carroll \& Shabana, 2010; Eccles, loannou, \& Serafeim, 2014) and that integrated reporting ties in with the creation of organisational legitimacy (De Villiers \& Alexander, 2014; Solomon \& Maroun, 2012) 
and to give the impression that South Africa's corporate reporting and corporate governance systems are world-class (Maroun, Coldwell, \& Segal, 2014).

Institutional investors are considered to be the primary audience for integrated reports (IIRC, 2013). Even though the integrated report is not only intended for a specialised audience such as institutional investors and financial analysts, but a far broader range of stakeholders, it is still mostly aimed at informed readers (Rensburg \& Botha, 2014) and compiled with the informed reader in mind. The integrated report, especially the non-financial part (De Klerk \& De Villiers, 2012), should aim to present information about a company's legitimacy to, amongst others, potential investors, internal stakeholders (employees and managers), supply chain (customers and suppliers), the government (regulatory authorities, occupational health and safety, regional and district councils), and society (De Villiers, Rouse, \& Kerr, 2016). According to West (2009), it is specifically the general stakeholder approach of integrated reporting practice that is critical for the continued development of South Africa. In addition, the privilege to invest in a listed company is not the domain of only large investors, investment managers, and stockbrokers anymore. Any individual can now be their own stockbroker and buy shares through their personal bank account.

The economically active population of South Africa (ages 25 to 64) amount to 25 million people (Statistics South Africa, 2017). Of these individuals, 17 million (68\%) have completed secondary school and 3 million (12\%) hold a post-secondary qualification. Only 2 million (10\%) of the economically active population uses English as a first or home language, even though English is the business language of South Africa (Rensburg \& Botha, 2014; Statistics South Africa, 2017). Most interested and affected parties only have access to publicly available information of a company, and the integrated report is supposed to fill the information gap left by annual reports (De Villiers \& Van Staden, 2010a, 2010b), as it provides more information directly related to the strategy of the organisation (Lambooy, Hordijk, \& Bijveld, 2014; Phillips, Watson, \& Willis, 2011). One of the key characteristics of a good report is its ability to convey the necessary information to its wide audience in a way that is easy to read and understand and is appropriate for decision-making (Buitendag, Fortuin, \& de Laan, 2017; Chatterjee, 2008; Cook \& Sutton, 1995; Eugene Baker III \& Kare, 1992; Jones, 1988; Pashalian \& Crissy, 1952; Rahman, 2014; Richards \& van Staden, 2015). Unfortunately, many studies have found that financial reports are lacking in readability (Anderson, 1998; Bartlett \& Chandler, 1997; Hrasky \& Smith, 2008; Schroeder \& Gibson, 1992), in part as a result of increasing complexity (Eccles \& Saltzman, 
2011). Bartlett and Chandler (1997) and Anderson (1998) found that investors do not necessarily read corporate reports nor find them useful, which could be a function of reports being difficult to read. Readability is positively associated with effective communication (Courtis \& Hassan, 2002; Subramanian, Insley, \& Blackwell, 1993) and was found to even affect the outcome of analysts' forecasts (Lehavy, Li, \& Merkley, 2011).

A number of researchers have found that good integrated reporting serves as a tool to enhance reputation, to create corporate legitimacy, as well as to manage for impressions (Ahmed Haji \& Anifowose, 2016; Eccles \& Saltzman, 2011; Steyn, 2014; Stubbs \& Higgins, 2014). Rensburg and Botha (2014) noted that, as a result of the diversity of different stakeholder groups, one can understand why companies focus their communications on investors. However, it remains imperative that companies communicate their overall philosophy and the value that they add to a broader stakeholder group. The question thus arises as to how companies address the readability of their reports in their attempt to obtain organisational legitimacy and manage impressions.

As per suggestions by Ahmed Haji and Anifowose (2016), this paper moves away from the 'whether', 'what' and 'why' of integrated reporting (Setia, Abhayawansa, Joshi, \& Huynh, 2015; Solomon \& Maroun, 2012; Wild \& van Staden, 2013), to focus on 'how' (Ahmed Haji \& Hossain, 2016) integrated reporting is done. This paper is an exploratory study to review and discuss the general readability of integrated reports of JSE listed companies, as part of an evaluation of the usefulness of integrated reports. South Africa is a unique research environment, with its eleven official languages, challenges in education provision, and turbulent political environment (Rensburg \& Botha, 2014; Rossouw \& West, 2009). While most countries are still trying to establish the need for integrated reports (Slack \& Tsalavoutas, 2017), most companies listed on the JSE already prepare integrated reports. For these reasons it is considered best to evaluate companies in the South African setting separately.

Rensburg and Botha (2014) investigated the usefulness of integrated reports and the extent to which it is used by South African stakeholders, by means of a survey distributed to the general public (i.e. the 'broader' stakeholder group). They also tested stakeholders' perception regarding the understandability of integrated reports, but they did not specifically investigate readability. Their results do show, however, that companies should make an effort to communicate effectively to a broader range of stakeholders. Thus far, no studies have used readability 
measures to investigate the readability of integrated reports published by companies listed on the JSE. Most previous readability studies were conducted in different economies and focused on the chairman's statement or another limited portion of the annual report. This study evaluates the readability of the entire integrated reports of all companies listed on the JSE for 2015 and 2016 , by means of readability measures. In addition, a correlation is drawn between readability and the Ernst \& Young Excellence in Integrated Reporting Awards for 2015. The results indicate that integrated reports of companies listed on the JSE lack readability and that companies with less readable integrated reports are more likely to be rewarded in the Ernst \& Young Excellence in Integrated Reporting Awards.

A study into the readability of integrated reports is of interest to various stakeholders and interested parties. Firstly, for academics, the results present new findings regarding integrated reporting practice. Secondly, the findings of this study provides information to firms, investors, the JSE, and the International Integrated Reporting Council (IIRC), about how integrated reporting practice could be adjusted and improved. Thirdly, the results are also of interest to companies that plan to engage in integrated reporting in future as to how readability could enhance the value of their reports.

The next section of the paper presents a review of the literature on the theories that apply to this study, as well as on the topics of integrated reporting and readability. This is followed by a description of the research method, the results of an analysis of the readability of integrated reports, and a conclusion that discusses the results, the limitations of the study, and implications for future research.

\section{Literature review}

Issues such as the Global Financial Crisis, recent corporate failures, environmental disasters, and climate change, to name but a few, necessitate transparency from companies (Ahmed Haji \& Anifowose, 2016; Eccles, Serafeim, \& Krzus, 2011). Corporate value and reputation can be affected by corporate reporting (Hrasky \& Smith, 2008), therefore information beyond the financial statements is required for stakeholders to accurately gauge how companies are creating or destroying value (Buitendag et al., 2017; De Villiers \& Sharma, 2017; De Villiers \& van Staden, 2010b; Flower, 2015; Krzus, 2011b; Phillips et al., 2011; Rahman, 2014; Setia et al., 2015; Wee et al., 2016; Zhou, Simnett, \& Green, 2017). Roberts (2011) claims that a focus 
on the interests and expectations of all stakeholders is bound to be in the best interest of the company as a whole.

Integrated reporting has received significant attention from researchers and professional bodies (Higgins, Stubbs, \& Love, 2014; Setia et al., 2015; Wild \& van Staden, 2013), but it has not yet been 10 years since integrated reporting was introduced by the IIRC and recommended by the JSE, therefore research on the impact and value of integrated reporting is still fairly limited.

\subsection{Theoretical perspective}

Integrated reporting hinges on various management theories, including organisational legitimacy theory and impression management theory (Barnett \& Leoffler, 1979; Chatterjee, 2008; loana \& Adriana, 2014). Organisational legitimacy theory suggests that organisations use corporate reporting to legitimise an organisation's image of being a legitimate business with legitimate actions to all stakeholders (Ahmed Haji, 2013; Ahmed Haji \& Anifowose, 2016; Chatterjee, 2008; Chen, Jermias, \& Nazari, 2016; Cook \& Sutton, 1995; De Villiers \& Van Staden, 2006; Deegan, 2000; Hooghiemstra, 2000; Lai, Melloni, \& Stacchezzini, 2014; Magnaghi \& Aprile, 2014; Montecchia, Giordano, \& Grieco, 2016; Setia et al., 2015; Steyn, 2014; Williams \& Adams, 2013). Deegan and Rankin (1997) identify stakeholders to be, amongst others, equity investors, employees, analysts, advisors, business contact groups, government, taxpayers, ratepayers, consumers, lenders, creditors, suppliers, labour unions, the media, political parties, consumer and environmental protection societies, and regional pressure groups. There is thus a significantly wide audience for integrated reports, that include a multitude of parties apart from shareholders and creditors (Esterhuyse \& Wingard, 2016; Hutton, 2004).

Organisational legitimacy theory is derived from political economy theory and is founded on the idea of a social contract, which includes legal and non-legislated expectations from society (Chen et al., 2016; Deegan, 2000; Deegan \& Rankin, 1997; Hooghiemstra, 2000; Patten, 1991, 1992; Van Bommel, 2014). Organisational legitimacy in terms of corporate reporting means that organisations use certain disclosure strategies to shape their appearance (Ahmed Haji \& Anifowose, 2016; Wilmshurst \& Frost, 2000). The integrate report may have an effect on symbolic legitimacy (Ahmed Haji \& Anifowose, 2016) of companies listed on the JSE, especially in terms of providing evidence to the world regarding South Africa's reporting and corporate governance reforms (Maroun et al., 2014). Academic research has consequently found that 
corporate annual reports and integrated reports have in cases become merely ceremonial to display companies in the best light (Ahmed Haji \& Hossain, 2016; Brennan, Guillamon-Saorin, \& Pierce, 2009; Maroun, 2015; Vourvachis, Woodward, Woodward, \& Patten, 2016; Williams \& Adams, 2013).

Apart from symbolic legitimacy, companies use the information in published reports to manage public impressions (Adams, Larrinaga-González, Adams, \& McNicholas, 2007; Brennan et al., 2009; Chatterjee, 2008; Chen et al., 2016; Hooghiemstra, 2000; Magnaghi \& Aprile, 2014; Maroun, 2015; Melloni, Caglio, \& Perego, 2017; Stanton, Stanton, \& Pires, 2004; Sydserff \& Weetman, 1999). Even though impression management theory was initially coined to explain the behaviour of an individual, the theory has been extended to organisations to explain the actions of organisations in terms of legitimacy theory (Hooghiemstra, 2000; Neu, Warsame, \& Pedwell, 1998). In this study, strategies of impression management theory and the symbolic perspective of legitimacy theory are evaluated in terms of how easy it is to read and understand an integrated report (Ahmed Haji \& Hossain, 2016; Chatterjee, 2008; Deegan \& Rankin, 1997; $\mathrm{Neu}$ et al., 1998). As early as 1974, Morton (1974) found a correlation between the understandability of disclosures and the extent to which those disclosures were thought to have a positive or negative impact on investment decisions. Magnaghi and Aprile (2014) also found a majority of positive disclosures in the reports they evaluated. There are various approaches to impression management in corporate reporting, with the majority of these focussed on ways to hide negative information and promote positive information (Brennan et al., 2009; Maas, Schaltegger, \& Crutzen, 2016; Melloni et al., 2017; Stacchezzini, Melloni, \& Lai, 2016). However, the type of language used in a report, for example formal versus informal, can also act as a means to manipulate the reader towards a certain image of the organisation. Courtis and Hassan (2002) investigated the effect of bilingual narrative reporting and found that indigenous language reports are easier to read than the English versions, which affect the impressions of international investors. Language can thus also give a specific impression of the company that prepares the document (Hooghiemstra, 2000), which is embedded in organisational legitimacy (Melloni et al., 2017).

\subsection{Integrated reporting}

The integrated report has its origin in the annual report, traditionally the main form of formal communication between a company and its stakeholders, which include information more than 
only the financial statements, such as a chairman's letter and an audit report (Anderson, 1998; Chatterjee, 2008; Stanton et al., 2004). As an advancement of the annual report, an integrated report provides information on companies' performance in terms of financial, environmental, social, and governance issues and links the relationships between these aspects (Eccles \& Saltzman, 2011; Krzus, 2011b; Lambooy et al., 2014). Information over and above the financial is necessary in this new age where a significant amount of a company's assets are intangible, for example corporate image, reputation, and employee motivation. In addition, integrated reporting is supposed to overcome reporting problems of being too lengthy, technical, and of silo-thinking (Kim, Maas, \& Perego, 2017; Wild \& van Staden, 2013). According to Eccles and Armbrester (2011), integrated reporting is supposed to bring to its internal users a better understanding of financial and non-financial performance, and to external users comprehensive information in terms of non-financial metrics, capital markets, as well as regulatory risk.

The need for integrated reporting in South Africa lies in corporate governance reforms, as brought about by the King Code of Governance Principles for South Africa (IoDSA, 2009) to enhance South Africa's reputation and competitiveness on a global scale (De Villiers, Rinaldi, \& Unerman, 2014). Since the first King Code was published in 1994, many advances have been made and the latest version, King IV, was released in 2016 and implemented from 1 April 2017. According to Ahmed Haji and Anifowose (2016), integrated reporting is also a positive mechanism to reduce corruption and social inequalities by tracking organisational performance in terms of non-financial factors, for example employment equity. Kim et al. (2017) found that integrated reporting improves the perceptions of report users and increases the reports' ability to inform decisions, which is essential in an environment where the integrated report is prepared for a wider stakeholder group and not only shareholders, as per Rossouw and West (2009).

Integrated reporting sets out to provide non-technical information about an organisation's attempts to create value in terms of six capitals, namely financial, manufactured, intellectual, human, social, and natural capital (Ahmed Haji \& Hossain, 2016; Barth, Cahan, Chen, \& Venter, 2017; Brown \& Dillard, 2014; Coulson, Adams, Nugent, \& Haynes, 2015; IIRC, 2013; IoDSA, 2009; Krzus, 2011b; Lambooy et al., 2014; Magnaghi \& Aprile, 2014; Phillips et al., 2011; Wild \& van Staden, 2013; Zhou et al., 2017). The stakeholders of integrated reports are not only external, but also internal to a company (Chen et al., 2016; Eccles \& Armbrester, 2011; Setia et al., 2015; Wee et al., 2016; Wild \& van Staden, 2013; Williams \& Adams, 2013), as these reports are used to enhance integrated thinking and to effect organisational change inside 
organisations (Adams et al., 2007; Bouten \& Hoozée, 2013, 2015; Brown \& Dillard, 2014; Setia et al., 2015; Stacchezzini et al., 2016; Stubbs \& Higgins, 2014; Tilt, 2006). Integrated reports are supposed to demonstrate value-to-society (Flower, 2015; Setia et al., 2015), rather than valueto-investors, but are still mainly produced with investors in mind (Rensburg \& Botha, 2014). Ongoing corporate reforms, integrated thinking, and integrated reporting are thus aimed at addressing the interests of a wider stakeholder group than before (De Villiers, Venter, \& Hsiao, 2016; Hutton, 2004; Krzus, 2011b; West, 2006). Studies by De Villiers and Van Staden (2010a, 2010b), show that investors in South Africa, the US, Australia, and the UK are all interested in environmental information for decision-making purposes. Integrated reporting is not about higher quantities of information, but rather better quality information to provide greater understanding of the operations of a company (Hutton, 2004).

Krzus (2011a) and De Villiers, Venter, et al. (2016) summarise the benefits of integrated reporting, in that it improves clarity regarding the relationship between financial and nonfinancial performance, allows for better informed decisions, ensures better engagement with all stakeholders to allow for the constant change a society sees, and allows for conversations that reduce reputational risk. However, even with guidance from the IIRC, the Integrated Reporting Committee of South Africa (IRCSA), and the JSE's 'apply or explain' requirement, companies can still exercise significant judgement on how they wish to implement integrated reporting (Setia et al., 2015).

Integrated reporting has received its share of criticism, with comments that it has not lived up to what it stood for (De Villiers \& Sharma, 2017; Flower, 2015). Milne and Gray (2013), as well as Brown and Dillard (2014), are of the opinion that integrated reporting is too focused on the investor and disregards other stakeholders that form part of all the divergent groups that make up the stakeholders of an organisation (Van Bommel, 2014). Empirical research has found that companies fail in the reporting process in terms of a lack of connectivity in information, poor materiality determination, and a lack of reliability and completeness of integrated reports (Ahmed Haji \& Hossain, 2016; IRCSA, 2011; Wild \& van Staden, 2013). There is also a bias towards writing positive information different to the negative in an attempt to make the negative information less noticeable (Ahmed Haji \& Hossain, 2016; Brennan et al., 2009; Lo, Ramos, \& Rogo, 2017; Solomon \& Maroun, 2012), also referred to as the 'obfuscation hypothesis' (Brennan et al., 2009; Courtis, 1998; Melloni et al., 2017; Rutherford, 2002; Smeuninx, De Clerck, \& Aerts, 2016). Critics of integrated reporting claim that these reports are complex and 
that stakeholders find them hard to understand (Ioana \& Adriana, 2014). Researchers find that, over time, the amount of reporting increases, but that it tend to be a corporate legitimisation strategy and a way to manipulate impressions, with language that appeases stakeholders (Brennan et al., 2009; Setia et al., 2015; Solomon \& Maroun, 2012).

\subsection{Readability}

Readability formulae provide a quantitative way to predict how readable a target audience find a text to be (Courtis, 1986; Eugene Baker III \& Kare, 1992; Jones \& Shoemaker, 1994; Klare, 1974). Readability has been used in communication, psychology and education to indicate how easy it is to understand a piece of writing. Readability formulae make use of correlation and regression of associations between elements of writing, for example word length, sentence length, etc. (Barnett \& Leoffler, 1979). According to Barnett and Leoffler (1979), readability measures provide a form of feedback to the organisations that prepare accounting reports they provide evidence not only to establish whether stakeholders will use information, but if they will read it and be able to comprehend it as well.

One of the most well-known measures of readability is the Flesch Reading Ease, the formula of which is based on factors of word and sentence length (Flesch, 1948). The higher the score of the Flesch Reading Ease, the better the readability of the text. Therefore, a Flesch Reading Ease score of 30 is readable at college-graduate level, while a score above 90 is readable by a fifth-grader (Barnett \& Leoffler, 1979; Courtis, 1986). In addition to the Flesch Reading Ease, one can evaluate the variability between scores of sections within a report (Linsley \& Lawrence, 2007). An updated version of the Flesch Reading Ease is the Flesch-Kincaid, which was developed for use by US Navy enlisted personnel (Kincaid, Fishburne Jr, Rogers, \& Chissom, 1975 ) and is the readability standard for the US Department of Defense (Kincaid, Aagard, O' Hara, \& Cottrell, 1981). The score derived from the Flesch-Kincaid formula gives an indication of the grade level a reader must be to comfortably read and comprehend the material under consideration. Another well-known measure of readability is the Gunning Fog formula (Gunning, 1969). The Gunning Fog Index categorises writing into categories that range from youth magazine to technical book. A Gunning Fog of 14, for example, indicates that the material will only be read by a reader with a special interest, motivation or education. An index of 17 refers to scientific or technical materials that have little social accessibility (Courtis, 1986). 
The Flesch Reading Ease and other readability measures are widely criticised for a number of reasons (Clatworthy \& Jones, 2001; Jones, 1988). Firstly, the focus of these measures are mainly on word and sentence length, and thus ignore features such as syntax, style, format, graphics, and any other attributes not covered by word and sentence length (Courtis, 1998; Dreyer, 1984). Secondly, the measures have not advanced in years and can therefore not account for natural changes in language since their origin. Thirdly, they were developed to evaluate the reading difficulty of children's books and are thus not specifically suited to adult reading material. Finally, researchers tend to misinterpret the results from readability measures as indicators of understandability. Readability measures cannot take into account the conceptual background of the reader, nor the conceptual load in the text (Courtis, 1986, 1995; Jones, 1996; Jones \& Shoemaker, 1994; Stevens, Stevens, \& Stevens, 1992; Sydserff \& Weetman, 1999). However, readability measures are reliable, valid and practicable (Jones, 1988; Klare, 1974; Richards \& van Staden, 2015).

The Cloze Readability Procedure is a more accurate way to test understandability (Adelberg, 1979; Stevens et al., 1992). Cloze uses a piece of text, but leaves out every $\mathrm{n}^{\text {th }}$ word for a participant to fill in. The extent to which the reader can correctly complete the missing text, indicates the extent of understandability. However, Cloze requires human participants, which can make it time-consuming and costly (Jones, 1988). Sydserff and Weetman (1999) suggest the use of a texture index, where a search is conducted for certain words that allude to complexity and thus understandability rather than only readability. However, the use of a texture index is also time consuming.

Thus, despite criticism, readability measures are still widely used and recommended for readability studies due to it being an objective test, its ease of use, its understandability, and because it can be used to compare readability of different texts (Clatworthy \& Jones, 2001; Courtis, 1998; Eugene Baker III \& Kare, 1992; Klare, 1974). Courtis and Hassan (2002) also found it to be cost-effective and, as stated by Subramanian et al. (1993), it does not need human participation, therefore issues such as selection validity threats are eliminated. According to Courtis (1986) and Subramanian et al. (1993), these 'simple' measures can provide a useful and reliable indication of readability if one uses it with care and with an understanding of its limitations. Since sentence complexity is the real indicator of difficulty to read, sentence length correlates closely to complexity and can thus be used as an approximation of understandability (Courtis, 1986, 1995). 
In addition to readability measures, the use of active versus passive sentences plays an important role in readability (Bonsall, Leone, Miller, \& Rennekamp, 2017; Schroeder \& Gibson, 1992; Smith \& Taffler, 1992; Sydserff \& Weetman, 1999; Thomas, 1997). Sydserff and Weetman (1999) contends that passive sentences are often used in cases where a company is not performing well.

The US Securities Act of 1933 consistently attempts to make disclosures more readable (Bonsall et al., 2017; Firtel, 1998; Smeuninx et al., 2016) and instituted a policy for 'Plain English' writing. According to Firtel (1998), it is a myth that the average investor can understand corporate disclosure. The regulation to enhance 'Plain English' is to ensure that companies use clear language, avoid vague language to hide negative information, and ensure that all investors can understand disclosures and make informed decisions (Li, 2008). Readability is the cornerstone of understandability, since a document that is easy to read facilitates comprehension, retention, reading speed, and reading persistence (Sattari, Pitt, \& Caruana, 2011). The SEC handbook on plain English writing alludes to six principles, namely short sentences, everyday language, active voice, tables and bulleted lists where possible, not legal or business jargon, and no double negatives (Li, 2008).

A number of studies have applied content analysis on the narratives of annual reports from an impression management theory point of view (Adelberg, 1979; Clatworthy \& Jones, 2001; Courtis, 1986, 1995, 1998; Courtis \& Hassan, 2002; Eugene Baker III \& Kare, 1992; Jones, 1988, 1996; Lehavy et al., 2011; Li, 2008; Parker, 1982; Rutherford, 2002; Smith \& Taffler, 1992; Stevens et al., 1992; Subramanian et al., 1993; Sydserff \& Weetman, 1999) and the next section provides an overview of a selection of these studies.

\subsection{Readability of corporate reports}

There has as yet not been any studies to test the readability of integrated reports from companies listed on the JSE, South Africa. However, there has been numerous studies to test the readability of selected sections of annual reports (Courtis, 1986). Table 1 presents a summary of selected annual report readability studies that have been conducted in the past, with a short note about their findings. 
Table 1: Summary of a selected studies on the readability of accounting reports

\begin{tabular}{|c|c|c|c|c|}
\hline Author(s) and year & Country & Sample & Measure & $\begin{array}{l}\text { Main findings } \\
\text { on readability }\end{array}$ \\
\hline $\begin{array}{l}\text { Pashalian and Crissy } \\
\text { (1952) }\end{array}$ & US & $\begin{array}{l}26 \text { annual reports from } \\
1946\end{array}$ & Flesch Reading Ease & Difficult to very difficult \\
\hline $\begin{array}{l}\text { Soper and Dolphin } \\
\text { (1964) }\end{array}$ & US & $\begin{array}{l}25 \text { annual reports from } \\
1964\end{array}$ & Flesch Reading Ease & Very difficult \\
\hline Smith and Smith (1971) & US & $\begin{array}{l}49 \text { sets of financial } \\
\text { statement footnotes from } \\
\text { the Top } 50 \text { Fortune } 500 \\
\text { companies }\end{array}$ & $\begin{array}{l}\text { Flesch Reading Ease } \\
\text { and Dale-Chall }\end{array}$ & $\begin{array}{l}\text { Very difficult, need } \\
\text { postgraduate degree }\end{array}$ \\
\hline Parker (1982) & Australia & $\begin{array}{l}\text { Chairman's address and } \\
\text { footnotes of } 10 \text { reports } \\
\text { from } 1980\end{array}$ & Fog Index & $\begin{array}{l}\text { Equivalent to technical } \\
\text { books and scientific } \\
\text { literature }\end{array}$ \\
\hline Courtis (1986) & Canada & $\begin{array}{l}\text { Chairman's address and } \\
\text { footnotes of } 46 \text { annual } \\
\text { reports from } 1982 \text { and } 96 \\
\text { from } 1983\end{array}$ & $\begin{array}{l}\text { Flesch Reading Ease } \\
\text { and Fog Index }\end{array}$ & Difficult to very difficult \\
\hline Jones (1988) & UK & $\begin{array}{l}\text { Chairman's report of one } \\
\text { company from } 1952 \text { to } \\
1985\end{array}$ & Flesch Reading Ease & Mostly difficult to read \\
\hline $\begin{array}{l}\text { Eugene Baker III and } \\
\text { Kare (1992) }\end{array}$ & US & President's letter & $\begin{array}{l}\text { Flesch Reading Ease, } \\
\text { Fog Index, and } \\
\text { Readability Index }\end{array}$ & $\begin{array}{l}\text { Reader need } 13 \text { to } 16 \\
\text { years' education }\end{array}$ \\
\hline $\begin{array}{l}\text { Schroeder and Gibson } \\
\text { (1992) }\end{array}$ & US & $\begin{array}{l}\text { Summary annual reports } \\
\text { from } 1986 \text { and } 1987\end{array}$ & $\begin{array}{l}\text { Use of passive voice, } \\
\text { Flesch/Kincaid Index }\end{array}$ & Difficult \\
\hline $\begin{array}{l}\text { Smith and Taffler } \\
\text { (1992) }\end{array}$ & UK & $\begin{array}{l}\text { Chairman's narrative } \\
\text { from } 1978 \text { to } 1985\end{array}$ & $\begin{array}{l}\text { Flesch Reading Ease, } \\
\text { Cloze Procedure, Lix } \\
\text { Test }\end{array}$ & Difficult \\
\hline $\begin{array}{l}\text { Subramanian et al. } \\
\text { (1993) }\end{array}$ & US & $\begin{array}{l}\text { Letter to shareholders of } \\
60 \text { annual reports for } \\
1987 \text { and } 1988\end{array}$ & $\begin{array}{l}\text { Flesch Reading Ease, } \\
\text { Flesch-Kincaid Grade } \\
\text { Level score, and Fog } \\
\text { Index }\end{array}$ & Difficult to very difficult \\
\hline Courtis (1995) & Hong Kong & $\begin{array}{l}\text { Chairman's addresses } \\
\text { and footnotes of } 32 \\
\text { annual reports for } 1986 \\
\text { and } 1991 \text {. }\end{array}$ & $\begin{array}{l}\text { Flesch Reading Ease, } \\
\text { Fog and Lix measures }\end{array}$ & Difficult \\
\hline $\begin{array}{l}\text { Courtis and Hassan } \\
\text { (2002) }\end{array}$ & $\begin{array}{l}\text { Hong Kong, } \\
\text { China and } \\
\text { Malaysia }\end{array}$ & $\begin{array}{l}\text { Chairman' statements } \\
\text { and footnotes from } 33 \\
\text { Hong Kong companies, } \\
32 \text { Chinese companies } \\
\text { and } 53 \text { Malay companies }\end{array}$ & $\begin{array}{l}\text { Flesch Reading Ease, } \\
\text { Yang (Chinese) and } \\
\text { Yunus (Malay) }\end{array}$ & $\begin{array}{l}\text { English - very difficult } \\
\text { Chinese - difficult } \\
\text { Malay - fairly difficult }\end{array}$ \\
\hline $\begin{array}{l}\text { Linsley and Lawrence } \\
\text { (2007) }\end{array}$ & UK & $\begin{array}{l}\text { Risk disclosures of } 25 \\
\text { companies for } 2001\end{array}$ & $\begin{array}{l}\text { Flesch Reading Ease, } \\
\text { McCall-Crabbs } \\
\text { Standard Test Lessons } \\
\text { in Reading, variability in } \\
\text { Flesch Scores }\end{array}$ & Difficult to very difficult \\
\hline $\begin{array}{l}\text { Hrasky and Smith } \\
(2008)\end{array}$ & Australia & $\begin{array}{l}68 \text { company concise } \\
\text { reports with a control } \\
\text { sample of } 100 \text { non- } \\
\text { concise reports. } \\
\text { Chairperson's statement } \\
\text { or letter to shareholders }\end{array}$ & $\begin{array}{l}\text { Flesch Reading Ease, } \\
\text { count of passive } \\
\text { sentences }\end{array}$ & $\begin{array}{l}\text { Difficult to read, regardless } \\
\text { whether full or concise } \\
\text { report. }\end{array}$ \\
\hline Li (2008) & US & $\begin{array}{l}\text { Annual reports from } 1994 \\
\text { to } 2004\end{array}$ & $\begin{array}{l}\text { Flesch Reading Ease, } \\
\text { Fog Index, annual } \\
\text { report length (in words) }\end{array}$ & Very difficult \\
\hline Lehavy et al. (2011) & US & $\begin{array}{l}\text { Reports available on the } \\
\text { SEC EDGAR filings } \\
\text { database from } 1995 \text { to } \\
\text { 2006, with some }\end{array}$ & Fog Index & Very difficult \\
\hline
\end{tabular}




\begin{tabular}{|c|c|c|c|c|}
\hline & & restrictions & & \\
\hline Sattari et al. (2011) & US & $\begin{array}{l}\text { Mission statements from } \\
100 \text { firms }\end{array}$ & $\begin{array}{l}\text { Flesch Reading Ease } \\
\text { Score, and the Flesch- } \\
\text { Kincaid Grade Level } \\
\text { Score }\end{array}$ & Very difficult \\
\hline Rahman (2014) & Malaysia & $\begin{array}{l}\text { Chairman's narrative for } \\
\text { one company from } 1962 \\
\text { to } 2009\end{array}$ & Flesch reading Ease & Difficult \\
\hline $\begin{array}{l}\text { Richards and van } \\
\text { Staden (2015) }\end{array}$ & New Zealand & $\begin{array}{l}180 \text { Annual reports } \\
\text { between } 2006 \text { and } 2010 .\end{array}$ & $\begin{array}{l}\text { Flesch Reading Ease, } \\
\text { Flesch-Kincaid Grade } \\
\text { Level score, Fog Index, } \\
\text { and Smog Index }\end{array}$ & Very difficult \\
\hline $\begin{array}{l}\text { Boritz, Hayes, and } \\
\text { Timoshenko (2016) }\end{array}$ & US & $\begin{array}{l}\text { SOX } 404 \text { reports for } 2004 \\
\text { to } 2014\end{array}$ & Fog Index & Very difficult \\
\hline Smeuninx et al. (2016) & $\begin{array}{l}\text { USA, UK, } \\
\text { Europe, } \\
\text { Australia, } \\
\text { India }\end{array}$ & $\begin{array}{l}470 \text { reports from } 2012 \text {, } \\
\text { including CEO letters, } \\
\text { sustainability letters, and } \\
\text { sustainability reports }\end{array}$ & $\begin{array}{l}\text { Flesch Reading Ease, } \\
\text { Flesch-Kincaid Grade } \\
\text { Level score, and Fog } \\
\text { Index }\end{array}$ & Very difficult \\
\hline Bonsall et al. (2017) & US & $\begin{array}{l}\text { All } 10-K \text { documents from } \\
1994 \text { to } 2012 \text { with some } \\
\text { data restrictions }\end{array}$ & $\begin{array}{l}\text { Plain English attributes, } \\
\text { e.g. passive voice, long } \\
\text { sentences, etc. Bog } \\
\text { Index }\end{array}$ & Very difficult \\
\hline Lo et al. (2017) & US & $\begin{array}{l}\text { Reports available on the } \\
\text { SEC EDGAR filings } \\
\text { database from } 2000 \text { to } \\
2012 \text {, with some } \\
\text { restrictions }\end{array}$ & Fog Index & Very difficult \\
\hline Melloni et al. (2017) & Worldwide & $\begin{array}{l}\text { IIRC Pilot Programme } \\
\text { reports } 2013 \text { and } 2014\end{array}$ & $\begin{array}{l}\text { Flesch Reading Ease, } \\
\text { Flesch-Kincaid Grade } \\
\text { Level score, and Fog } \\
\text { Index }\end{array}$ & Very difficult \\
\hline
\end{tabular}

Source: Author's own compilation

In summary, material from annual reports can range from difficult to very difficult to read (Jones \& Shoemaker, 1994) and beyond the comprehension of a large percentage of the adult and investor populations of the counties in which the studies were conducted (Courtis, 1995; Courtis \& Hassan, 2002). In addition, it appears as if readability has decreased over time (Rahman, 2014). The use of a more objective measure, such as the Cloze Readability Procedure, provide similar results. Adelberg (1979) found that even individuals in the accounting profession find it hard to properly understand annual reports due to the technical nature of the information contained in the reports.

One should take into account that corporate reports are prepared by different individuals with different backgrounds and that the style and tone could differ remarkably as a result of that (Rutherford, 2002). Through interviews, Rutherford (2002) was able to establish that reports also differ as a result of company characteristics - for example, when a company is performing poorly, the narrative tend to be shorter and more complex in an attempt to 'obfuscate' the negative message. 


\section{Research method}

\subsection{Sampling}

The sample for this study consist of all the companies listed on the JSE in 2015 and 2016, except where information is not available, such as a delisting since 2015 or where a new company was only listed in 2016. Since 1 March 2010, all South African listed companies are compelled to prepare an integrated report, or explain why they decided not to. For this paper, only integrated reports from South Africa are considered, since it is still only rarely used internationally (Chen et al., 2016). Where a company does not yet implement an integrated report, either as a result a dual listing in another country or because the company still need to fully implement integrated reporting principles, the report is excluded from the sample. The sample also excludes annual reports that are not explicitly called an 'integrated report' nor have a section referred to as an 'integrated report'. Note that reports excluded from the study do comply with the principles of King III, as required by the JSE listing requirements for those financial years, but only refrained from calling their report an 'integrated report' or did not explicitly state that it complies with integrated reporting principles since it was not yet a mandatory requirement up to 31 March 2017.

For this first exploratory paper the integrated reports for two years, namely 2015 and 2016, are analysed and evaluated. All the integrated reports evaluated in this study were obtained from the IRESS financial database. They were then converted from the PDF to a MS Office Word format. Due to the number of companies listed on the JSE and the subsequent volume of reports to prepare and analyse, the author conducted the study with the most recent available financial years to assess what the current situation looks like. Additional years will be added to the database over time.

In some cases the PDF version of the integrated report was secured and could not be converted to a Word document, which was the case for four companies in 2015 and eight companies in 2016. In addition, a thorough investigation was conducted to ensure that all available integrated reports are included in the sample. Where the title of the report is not stated as integrated report', a detailed search was conducted to establish whether the company implements the principles of integrated reporting or have a separate section inside the annual report that is called an integrated report. 
Refer to Table 2 for information about the number of integrated reports included in the sample. The reports are analysed per industry to account for differences in characteristics between industries, as well as to account for size differences between industries.

Table 2: Integrated reports analysed

\begin{tabular}{|lrrr|}
\hline \multicolumn{1}{|c}{2015} & $\begin{array}{c}\text { Number of } \\
\text { companies } \\
\text { per industry }\end{array}$ & $\begin{array}{c}\text { Number } \\
\text { of } \\
\text { integrated } \\
\text { reports }\end{array}$ & Percentage \\
\hline Basic materials & 52 & 40 & $77 \%$ \\
Consumer goods & 22 & 15 & $68 \%$ \\
Consumer services & 38 & 35 & $92 \%$ \\
Financials & 100 & 65 & $65 \%$ \\
Healthcare & 7 & 6 & $86 \%$ \\
Industrials & 60 & 50 & $83 \%$ \\
Technology & 8 & 7 & $88 \%$ \\
Telecommunications & 5 & 5 & $100 \%$ \\
Total & 292 & 223 & $76 \%$ \\
\cline { 2 - 5 } & \multicolumn{3}{|c}{} \\
\hline
\end{tabular}

\begin{tabular}{|lrrr|}
\hline \multicolumn{1}{|c}{2016} & $\begin{array}{c}\text { Number of } \\
\text { companies } \\
\text { per industry }\end{array}$ & $\begin{array}{c}\text { Number } \\
\text { of } \\
\text { integrated } \\
\text { reports }\end{array}$ & Percentage \\
\hline Basic materials & 51 & 42 & $82 \%$ \\
Consumer goods & 22 & 16 & $73 \%$ \\
Consumer services & 38 & 36 & $95 \%$ \\
Financials & 100 & 73 & $73 \%$ \\
Healthcare & 7 & 5 & $71 \%$ \\
Industrials & 60 & 53 & $88 \%$ \\
Technology & 8 & 7 & $88 \%$ \\
Telecommunications & 5 & 5 & $100 \%$ \\
Total & 291 & 237 & $81 \%$ \\
\hline
\end{tabular}

Source: Author's own compilation

The Oil and Gas Industry was excluded from the study, since only one South African company in that industry prepared an integrated report. Since this company is double-listed in both the Oil and Gas, as well as the Industrials industries, the company's 2015 and 2016 reports are analysed as part of the Industrials Industry. 
From the numbers presented in Table 2, it appears that the industries of Consumer Goods and Financials contain the most companies who do not yet prepare an integrated report or do not call their annual report an integrated report. However, the number of integrated reports increased from 2015 to 2016.

The descriptive analysis is supplemented with a correlation study between the Ernst \& Young Excellence in Integrated Reporting Awards and readability for 2015. Ernst \& Young (EY), in collaboration with the University of Cape Town, evaluates the integrated reports of the Top 100 firms (based on market capitalisation) listed on the JSE yearly to establish its quality. The result of the analysis is a ranking and yearly awards (Ernst \& Young, 2012). The EY ranking is selected for this study, since the rating focuses on disclosure in terms of whether the integrated report gives the reader a sense of the fundamental issues important to the company (Barth et al., 2017), which is the essence of this study. The evaluation firstly ranks the Top 10 integrated reports, followed by a commendation for an 'Excellent' report and a commendation for a 'Good' report. The rest of the reports are classified as either 'Average' or 'Progress to be made'. As an additional analysis, the variables investigated in this study are correlated to the EY Integrated Reporting Award ranking of integrated reports.

The correlation analysis is conducted for the 2015 financial year alone, since there is a lagging effect between the financial year and the year of ranking (i.e. the ranking for the integrated reports of the 2015 financial year can only be presented in 2016). The $2017 \mathrm{EY}$ Integrated Reporting Award ranking of the 2016 integrated reports is not yet available at the time of writing. For purposes of this correlation, an EY Integrated Reporting Top 10 ranking is coded as a '1', an 'Excellent' ranking as a '2', a 'Good' ranking as a '3', an 'Average' ranking as a '4', and a 'Progress to be made' ranking as a ' 5 '.

\subsection{Analysis}

Organisations need to legitimise their actions (organisational legitimacy theory) and influence their stakeholders' perceptions of the company (impression management theory). See, for example Barnett and Leoffler (1979); Chatterjee (2008); Hooghiemstra (2000); loana and Adriana (2014); Maroun (2015); Melloni et al. (2017); Sydserff and Weetman (1999). The best way to accomplish legitimacy and management impressions is through the public reports companies make available (Patten, 1991; Wilmshurst \& Frost, 2000). However, complex 
language can impair he readability of integrated reports and, consequently, weaken the legitimacy and impression management functions of the integrated report. The aim of this first exploratory study into the readability of integrated reports is to establish whether the complexity of the language used in integrated reports facilitate or hamper legitimacy and impression management.

The software application 'Readability Studio 2015' was used to analyse the integrated reports using various types of readability measures. Readability measures and readability software was used, since it allows for analysis of multiple records of multiple pages relatively easily, quickly and objectively. Measures of understandability such as the Cloze Procedure relies on the use of focus groups, which is costly and time-consuming and relies on human subjectivity and biases. In addition it will be impossible to test the readability of the full reports of all the companies on the JSE if focus groups are used.

Because readability tests are used for different purposes, the developers of Readability Studio 2015 by Oleander Software indicate which tests are most suitable to the task at hand. The Flesch Reading Ease, Flesch-Kincaid, and Gunning-Fog measures are recommended for testing the readability of material that is meant for adult readers, for example technical reports. The three readability measures are calculated as follows:

- The Flesch Reading Ease is calculated as [206.835 - 0.846(number of syllables per 100 words) - 1.015(average sentence length in words)].

- The Flesch-Kincaid measure is calculated as $[(0.39 x$ average sentence length $)+(11.8 x$ average syllables per word) - 15.59].

- The Gunning Fog Index is calculated as [0.4 x (average number of words per sentence + percentage of 'hard' words in the passage)]. In this context, 'hard' words are defined as polysyllabic words.

In addition to these tests, the study also investigates the length and difficulty of the words used in the reports, as well as the use of passive sentences and 'wordy' items. A 'wordy' item refers to a phrase that is unnecessarily long, for example 'a case in point', 'a large number of', 'a majority of', 'exactness', et cetera. These phrases could have been replaced with something shorter and easier to understand. 
The results from Readability Studio 2015 are analysed in terms of descriptive statistics to provide an initial frame of reference from a limited dataset for future readability studies. According to Bedeian (2014), it is necessary to fully understand the descriptive statistics and relations between variables before more advanced statistical techniques are considered. Since this is an exploratory study into the readability of integrated reports, it is thus imperative to first get to grips with the basic aspects of the primary data. When more readability data has been generated over time, more intricate analysis of relationships between different variables and readability can be conducted.

\section{Results}

The results of an analysis of the readability of integrated reports from companies listed on the JSE show a general lack of readability. Table 3 depicts the basic descriptive statistical results for the readability of integrated reports in the different industries over the two years (2015 and 2016). The results are presented per industry. The readability results were averaged rather than summed so that the values correspond to the readability measure interpretation scales. The use of results in terms of average values assumes that the separate items a measure is composed of use the same response format and have equivalent error score variances (Bedeian, 2014). Since standard tests are applied to all the integrated reports, these assumptions are confirmed for the variables considered in this study.

The result from the Flesch Reading Ease formula ranges in value from zero to 100 and the lower the value, the more difficult the text (Flesch, 1979). The 30 to 50 bracket for the Flesch Reading Ease is indicative of Difficult material, for holders of an undergraduate degree (e.g. academic literature). The zero to 30 bracket is indicative of Very Difficult material, for holders of a postgraduate degree (e.g. scientific material). In 2015, the reading ease rating of integrated reports published by companies listed on the JSE was Very Difficult, in the order of scientific writing and with the implication that the reader should be in possession of a postgraduate degree. The rating improved somewhat in 2016, but the overall average remains in the upper bounds of the Difficult category, which is in the order of academic writing and implies that the reader is in need of at least an undergraduate degree to understand the material. Telecommunications and Consumer Services appears to have the most readable integrated reports, even though it is still very close to the category of Very Difficult. The most difficult-to- 
Table 3: Results from readability measures

\begin{tabular}{|c|c|c|c|c|c|c|c|c|c|c|c|c|c|c|}
\hline \multirow[b]{4}{*}{ Basic materials } & \multicolumn{7}{|c|}{2015} & \multicolumn{7}{|c|}{2016} \\
\hline & \multirow[t]{2}{*}{$\mathbf{n}$} & \multicolumn{2}{|c|}{$\begin{array}{c}\text { Flesch } \\
\text { Reading Ease }\end{array}$} & \multicolumn{2}{|c|}{ Flesch-Kincaid } & \multicolumn{2}{|c|}{ Gunning Fog } & \multirow[t]{2}{*}{$\mathbf{n}$} & \multicolumn{2}{|c|}{$\begin{array}{c}\text { Flesch } \\
\text { Reading Ease }\end{array}$} & \multicolumn{2}{|c|}{ Flesch-Kincaid } & \multicolumn{2}{|c|}{ Gunning Fog } \\
\hline & & Mean & SD & Mean & SD & Mean & SD & & Mean & SD & Mean & SD & Mean & SD \\
\hline & 40 & 21.15 & 3.21 & 16.59 & 0.83 & 15.93 & 0.87 & 42 & 30.19 & 2.57 & 15.71 & 0.65 & 15.74 & 0.72 \\
\hline Consumer goods & 15 & 29.87 & 2.90 & 15.55 & 0.71 & 16.13 & 0.89 & 16 & 30.69 & 3.28 & 15.43 & 0.91 & 15.98 & 0.83 \\
\hline Consumer services & 35 & 32.31 & 2.89 & 15.13 & 0.70 & 15.74 & 0.94 & 36 & 32.31 & 2.73 & 15.14 & 0.64 & 15.79 & 0.90 \\
\hline Financials & 65 & 31.63 & 3.34 & 15.31 & 0.72 & 15.88 & 0.82 & 73 & 31.07 & 3.79 & 15.38 & 0.75 & 15.91 & 0.80 \\
\hline Healthcare & 6 & 28.17 & 2.48 & 15.60 & 0.77 & 15.85 & 0.55 & 5 & 27.40 & 3.36 & 15.38 & 0.88 & 15.82 & 0.66 \\
\hline Industrials & 50 & 30.70 & 4.87 & 15.27 & 1.22 & 16.00 & 1.40 & 53 & 29.43 & 3.02 & 15.47 & 0.66 & 16.26 & 0.80 \\
\hline Technology & 7 & 30.00 & 2.65 & 15.44 & 0.78 & 15.93 & 0.42 & 7 & 30.43 & 1.72 & 15.46 & 0.52 & 15.74 & 0.61 \\
\hline Telecommunications & 5 & 32.80 & 3.70 & 15.06 & 0.59 & 15.36 & 1.14 & 5 & 32.60 & 1.82 & 14.88 & 0.34 & 15.34 & 0.57 \\
\hline Total & 223 & 29.41 & 5.33 & 15.52 & 1.00 & 15.90 & 1.00 & 237 & 30.65 & 3.29 & 15.42 & 0.71 & 15.93 & 0.81 \\
\hline
\end{tabular}

Note: Additional analysis to compare the mode, median and mean were performed and indicated very little deviation between the different measures, thus the mode and median are not presented here.

Source: Author's own compilation 
read integrated reports come from the Basic Goods, Consumer Goods, Industrials, and Health Care industries.

The Flesch-Kincaid measure indicates the grade (or education) level the reader need to be to understand the material ( $\mathrm{Li}, 2008)$. According to the results from the Flesch-Kincaid readability measure, the integrated reports of the companies listed on the JSE is Very Difficult to read and only understandable by university graduates or postgraduate students (i.e. individuals with an education of at least 15 years or more).

The Gunning Fog index uses a rating to indicate the difficulty level of the type of material, ranging from youth magazines to technical material (Courtis, 1986). Thus, the lower the rating obtained in the Gunning Fog index, the more readable the material. Technical books have an index of 19.5, Scientific Literature an index of 17.0 and Newspapers an index of 13.7. The Gunning Fog results obtained for the integrated reports of companies listed on the JSE indicate to material close to Scientific Literature and readable only by a 'college senior' by US standards, therefore a reader with approximately 15 years of education.

According to a report by Statistics South Africa (Statistics South Africa, 2017), the economically active population of South Africa (ages 25 to 64) amount to 25 million. Of these individuals, 17 million (68\%) completed secondary school, but only 3 million (12\%) hold a post-secondary qualification, which comprise of vocational training (28\%), certificates and diploma qualifications $(26 \%)$, and degree programmes (46\%). A post-secondary degree programme can imply total study years of between 15 and 20 years. The number of masters' and doctorate degree holders in South Africa can be considered negligible as a percentage of the total economically active population (Council on Higher Education, 2009). In addition to limitations in educational attainment, only 2 million (10\%) of the economically active population uses English as a first or home language, while the remaining population uses one or more of the other eleven national languages (Rensburg \& Botha, 2014; Statistics South Africa, 2017). Even though English is generally understood as the language of business, politics, and the media, it is only ranked fourth as a home language. These figures suggest that, due to the complex nature of company information, these reports might not be well understood by the general population and can be unnecessarily complex even for institutional investors and analysts. 
Apart from readability, other measures are investigated to complement the results of the readability tests. The number of words and number of pages of the integrated reports are not analysed separately in this study. Since many companies still prepare and present their annual financial statements separately from the integrated report, the length of the reports vary significantly (2015: between 37 and 552 pages; 2016: between 28 to 314 pages). However, the percentage complex words, long words and Fog hard words that make up the total integrated report is of interest. These percentages are presented in Table 4.

Table 4: Results from word difficulty that affect readability

\begin{tabular}{|c|c|c|c|c|c|c|c|c|}
\hline & \multicolumn{2}{|c|}{$\begin{array}{c}\text { Average of Total } \\
\text { words }\end{array}$} & \multicolumn{2}{|c|}{$\begin{array}{l}\text { Average of } \% \\
\text { complex words }\end{array}$} & \multicolumn{2}{|c|}{$\begin{array}{l}\text { Average of } \% \\
\text { long words }\end{array}$} & \multicolumn{2}{|c|}{$\begin{array}{l}\text { Average of } \% \\
\text { Fog hard words }\end{array}$} \\
\hline & 2015 & 2016 & 2015 & 2016 & 2015 & 2016 & 2015 & 2016 \\
\hline Basic materials & 48,157 & 43,469 & $28 \%$ & $25 \%$ & $45 \%$ & $42 \%$ & $20 \%$ & $20 \%$ \\
\hline Consumer goods & 35,422 & 35,670 & $26 \%$ & $25 \%$ & $43 \%$ & $43 \%$ & $21 \%$ & $20 \%$ \\
\hline Consumer services & 32,510 & 32,746 & $25 \%$ & $25 \%$ & $42 \%$ & $42 \%$ & $20 \%$ & $20 \%$ \\
\hline Financials & 36,597 & 33,092 & $25 \%$ & $26 \%$ & $42 \%$ & $42 \%$ & $20 \%$ & $20 \%$ \\
\hline Healthcare & 36,268 & 37,329 & $27 \%$ & $27 \%$ & $44 \%$ & $45 \%$ & $21 \%$ & $22 \%$ \\
\hline Industrials & 32,835 & 33,848 & $26 \%$ & $26 \%$ & $42 \%$ & $43 \%$ & $21 \%$ & $21 \%$ \\
\hline Technology & 36,298 & 36,743 & $26 \%$ & $26 \%$ & $42 \%$ & $42 \%$ & $20 \%$ & $20 \%$ \\
\hline Telecommunications & 47,711 & 37,793 & $25 \%$ & $25 \%$ & $42 \%$ & $41 \%$ & $19 \%$ & $20 \%$ \\
\hline
\end{tabular}

Source: Author's own compilation

Almost a quarter of the content of the integrated reports of companies listed on the JSE can be considered 'complex' and thus not part of the English used in everyday speech or reading. Since longer words affect readability, the average percentages of long words of over $40 \%$ is significant. Fog considers 'hard' words to be those with more than three syllables, except proper nouns, words created by the addition of 'ed' or 'es' (e.g. considered), and compound words consisting of two or more simpler words. Almost a fifth of each integrated report consists of these types of 'hard' words, which can affect readability.

Passive voice is sometimes used to obfuscate negative messages (Sydserff \& Weetman, 1999) and can be used to make a text seem more impressive. The same can be accomplished with so-called 'wordy' items. Table 5 presents the average number of passive sentences and 'wordy' items in the integrated reports. A 'wordy' item is defined as a phrase that contains too many 
words or overly complex words that can be replaced with simpler ones (e.g. 'over the course of' can be replaced with 'during' or 'throughout').

Table 5: The number of passive voice sentences and 'wordy' items

\begin{tabular}{|c|c|c|c|c|c|c|c|c|}
\hline & \multicolumn{4}{|c|}{ Passive voice sentences } & \multicolumn{4}{|c|}{ "Wordy" items } \\
\hline & \multicolumn{2}{|c|}{2015} & \multicolumn{2}{|c|}{2016} & \multicolumn{2}{|c|}{2015} & \multicolumn{2}{|c|}{2016} \\
\hline & Mean & SD & Mean & SD & Mean & SD & Mean & SD \\
\hline Basic materials & 601.80 & 294.09 & 621.62 & 304.12 & $3,542.20$ & $1,444.88$ & $3,754.24$ & $1,557.96$ \\
\hline Consumer goods & 531.53 & 259.85 & 499.19 & 280.84 & $3,144.00$ & $1,290.50$ & $3,152.00$ & $1,482.78$ \\
\hline Consumer services & 473.66 & 208.37 & 473.42 & 215.64 & $2,758.86$ & $1,015.69$ & $2,779.94$ & $1,032.17$ \\
\hline Financials & 556.72 & 316.86 & 466.33 & 229.12 & $3,221.95$ & $1,680.11$ & $2,901.51$ & $1,178.77$ \\
\hline Healthcare & 460.17 & 188.99 & 492.00 & 250.23 & $2,957.50$ & 919.59 & $3,240.20$ & $1,088.90$ \\
\hline Industrials & 486.42 & 191.83 & 501.47 & 183.49 & $2,915.66$ & 990.79 & $3,089.57$ & 964.84 \\
\hline Technology & 557.43 & 191.72 & 534.57 & 249.39 & $3,205.29$ & $1,005.10$ & $3,211.29$ & $1,331.25$ \\
\hline Telecommunications & 593.40 & 267.38 & 412.40 & 209.71 & $4,015.20$ & $1,215.96$ & $3,108.20$ & 876.75 \\
\hline Grand Total & 532.56 & 261.84 & 506.42 & 240.93 & $3,142.94$ & $1,347.90$ & $3,113.78$ & $1,237.51$ \\
\hline
\end{tabular}

Source: Author's own compilation

The results indicate to a large number of passive sentences and 'wordy' items present in the integrated reports, which can impact on its readability.

Table 6 presents a correlation matrix of the relationships between the variables for the Top 100 companies, based on market capitalisation. The small sample necessitates the use of a nonparametric test, therefore a Spearman's Rho is applied. For the correlation, the EY Integrated Reporting Award ranking is used as the dependent variable, while the various readability measures are included as independent variables. The total number of words and the total number of pages in the integrated reports are included as control variables to account for differences in the size of the reports. The sample includes only 75 integrated reports out of the Top 100 companies based on market capitalisation, since some of the reports do not conform to this study's definition of an integrated report (see Section 3.1).

The correlations between variables indicate three significant relationships, namely between the EY Integrated Reporting Award ranking and the Flesch Reading Ease, as well as the EY Integrated Reporting Award ranking and the percentage of both complex and long words. There is a positive relationship $(r=.276, p<0.05)$ between a company's propensity to be awarded in 
Table 6: Correlation between EY Ranking and readability measures

\begin{tabular}{|c|c|c|c|c|c|c|c|c|c|c|c|c|c|}
\hline & Mean & SD & 1 & 2 & 3 & 4 & 5 & 6 & 7 & 8 & 9 & 10 & 11 \\
\hline \multicolumn{14}{|l|}{ Dependent variable } \\
\hline \multicolumn{14}{|l|}{ Independent variables } \\
\hline 2. Flesch Reading Ease & 28.73 & 5.22 & $.276^{\star}$ & & & & & & & & & & \\
\hline 3. Flesch-Kincaid & 15.55 & 0.89 & -.115 & $-.816^{* *}$ & & & & & & & & & \\
\hline 4. Gunning Fog & 15.89 & 0.88 & -.010 & $-.413^{* *}$ & $.547^{\star *}$ & & & & & & & & \\
\hline 5. Complex words & 0.26 & 0.02 & $-.258^{*}$ & $-.832^{* *}$ & $.481^{\star *}$ & $.277^{*}$ & & & & & & & \\
\hline 6. Long words & 0.43 & 0.02 & $-.451^{\star *}$ & $-.745^{\star *}$ & $.405^{\star *}$ & .096 & $.868^{\star \star}$ & & & & & & \\
\hline 7. Fog hard words & 0.20 & 0.01 & -.132 & $-.270^{*}$ & .063 & $.591^{* *}$ & $.567^{\star \star}$ & $.462^{* *}$ & & & & & \\
\hline 8. Passive voice & 587.77 & 328.53 & .185 & -.039 & -.068 & .000 & -.010 & -.058 & .027 & & & & \\
\hline 9. Wordy items & $3,717.51$ & $1,565.88$ & -.027 & -.099 & -.067 & -.034 & .067 & .088 & .056 & $.905^{\star *}$ & & & \\
\hline \multicolumn{14}{|l|}{ Control variables } \\
\hline 10. Total words & $44,498.92$ & $18,971.06$ & -.028 & -.176 & -.001 & -.093 & .071 & .105 & -.077 & $.883^{\star \star}$ & $.959^{* *}$ & & \\
\hline 11. Number of pages & 156.77 & 78.95 & .046 & .040 & -.165 & -.043 & -.023 & -.004 & .100 & $.817^{\star *}$ & $.858^{* *}$ & $.806^{* *}$ & $\mathrm{~N} / \mathrm{A}$ \\
\hline
\end{tabular}

Notes:

a. Year $=2015 ; N=75$

b. ${ }^{*}$ Correlation is significant at the 0.05 level (2-tailed); ${ }^{* *}$ Correlation is significant at the 0.01 level (2-tailed)

Source: Author's own compilation 
the EY Integrated Reporting Award rankings and the Flesch Reading Ease. Since the Flesch Reading Ease indicates more readability the higher the value, the positive relationship indicates that reports considered less readable tend to obtain a higher EY Integrated Reporting Award ranking. A negative relationship can be observed for both the percentage of complex words $(r=$ -.258, $p<0.05)$ and the percentage long words $(r=-.451, p<0.01)$. This indicates that, the lower the percentage complex and long words, the lower the ranking on the EY Integrated Reporting Award scale. The reason for this may as simple as that the evaluation for the EY Integrated Reporting Award ranking is performed by accounting specialists, for whom the readability of integrated reports is natural as a function of their experience and their understanding of financial 'language'. However, it may provide evidence of the possibility that companies use complex writing to 'impress' its audience.

\section{Discussion and conclusion}

Despite the criticisms against readability formulae, especially its lack of ability to test understandability, it is still considered a sufficient starting point to evaluate the value of integrated reporting to the economically active population of South Africa. The results of a variety of readability measures indicate that integrated reports of companies listed on the JSE are perhaps largely unreadable to an individual without a tertiary qualification. From the results of the readability tests, no clear conjecture can be made as to the understandability of integrated reports, but prior research has found that readability can be used as a partial approximation of understandability (Courtis, 1986, 1995).

In line with previous readability studies performed on the annual reports of companies (refer to Table 1), the findings from this study indicates that only a small part of the entire audience for integrated reports of companies listed on the JSE will find it readable. This brings into question the usefulness of integrated reports to aid in creating organisational legitimacy, and to what extent the narrative in integrated reports can be successfully applied in managing people's impressions of the company. In addition, the correlation between the EY Integrated Reporting Award rankings and readability presents concerning results in that complex language in an integrated report seems to be rewarded.

The study has implications for various stakeholder groups. For academics, the results present new findings of a different viewpoint with regard to integrated reporting practice. For policy 
makers, regulators and authorities, the results from this study show that integrated reports are not accessible in terms of readability to all but a very small portion of the population that hold at least an undergraduate and in some cases a postgraduate degree. This may indicate a need for the IIRC and IRCSA to include some guidelines to the readability of integrated reports and for the JSE to revisit their disclosure policies. For companies, the results show a need for research into users' perceptions regarding the usefulness of integrated reports and also proper editing of reports to ensure they are useful to all the stakeholders they are intended for. The findings of this study is also of interest to investors, regulators, and the IIRC, as it suggests that integrated reporting is perhaps not used for the purpose it was intended for, namely informational content, but rather as a means to create organisational legitimacy and to manage impressions of the company.

\subsection{Limitations and future research}

The limitations to this study open up avenues for complementary future research. The most significant limitation, and simultaneous contribution, of this study is its South African context. As a limitation, the results cannot be generalised to the rest of the world. However, since South Africa is the only country where integrated reporting is strongly recommended and soon to be mandatory, its contribution is that features lacking from South African integrated reports can be addressed to improve the guidelines and processes for countries that wish to adopt mandatory integrated reporting in future. It thus makes sense to keep the focus on companies listed in South Africa for now. Future studies can, however, compare the integrated reports of South African companies with those from other countries.

Another limitation relates to one that was noted by Hrasky and Smith (2008), in that readability is a complex concept that does not easily translate into simple quantitative measurements. In addition, readability scores overlook some issues related to understandability, as mentioned by Richards and van Staden (2015). Other measures of understandability of the integrated report can be investigated in future research.

At present, integrated reports are mainly aimed at informed users (e.g. institutional investors) and therefore compiled with the informed reader in mind, even though the reports are supposed to be a source of information to a far wider range of stakeholders (IIRC, 2013; Rensburg \& Botha, 2014). Future research can investigate ways to make the integrated report more 
accessible to its wider audience by, amongst others, improving the readability of integrated reports.

The low correlation between the Ernst \& Young Excellence in Integrated Reporting Awards and readability indicate to other variables that have to be considered in future research to enhance the explanation of narrative complexity in integrated reports. Richards and van Staden (2015) specifically mention auditors, company age, turnover, geographic sectors, and various management indicators.

\section{References}

Adams, C. A., Larrinaga-González, C., Adams, C. A., \& McNicholas, P. (2007), "Making a difference: Sustainability reporting, accountability and organisational change", Accounting, Auditing \& Accountability Journal, Vol. 20 No. 3, pp. 382-402.

Adelberg, A. H. (1979), "Narrative disclosures contained in financial reports: means of communication or manipulation?", Accounting and Business Research, Vol. 9 No. 35, pp. 179-190.

Ahmed Haji, A. (2013), "Corporate social responsibility disclosures over time: evidence from Malaysia", Managerial Auditing Journal, Vol. 28 No. 7, pp. 647-676.

Ahmed Haji, A., \& Anifowose, M. (2016), "The trend of integrated reporting practice in South Africa: ceremonial or substantive?", Sustainability Accounting, Management and Policy Journal, Vol. 7 No. 2, pp. 190-224.

Ahmed Haji, A., \& Hossain, D. M. (2016), "Exploring the implications of integrated reporting on organisational reporting practice: Evidence from highly regarded integrated reporters", Qualitative Research in Accounting \& Management, Vol. 13 No. 4, pp. 415-444.

Anderson, R. H. (1998), "Regulating corporate annual reports in Australia", Business and economic History, Vol. No., pp. 522-534.

Barnett, A., \& Leoffler, K. (1979), "Readability of accounting and auditing messages", Journal of Business Communication, Vol. 16 No. 3, pp. 49-59.

Barth, M. E., Cahan, S. F., Chen, L., \& Venter, E. R. (2017), "The Economic Consequences Associated with Integrated Report Quality: Capital Market and Real Effects", SSRN. Retrieved from: https://papers.ssrn.com/sol3/papers.cfm?abstract id=2699409 
Bartlett, S. A., \& Chandler, R. A. (1997), "The corporate report and the private shareholder: Lee and Tweedie twenty years on", The British Accounting Review, Vol. 29 No. 3, pp. 245261.

Bedeian, A. G. (2014), "'More than meets the eye": A guide to interpreting the descriptive statistics and correlation matrices reported in management research", Academy of Management Learning \& Education, Vol. 13 No. 1, pp. 121-135.

Bonsall, S. B., Leone, A. J., Miller, B. P., \& Rennekamp, K. (2017), "A plain English measure of financial reporting readability", Journal of Accounting and Economics, Vol. 63 No. 2, pp. 329-357.

Boritz, J. E., Hayes, L., \& Timoshenko, L. M. (2016), "Determinants of the Readability of SOX 404 Reports", Journal of Emerging Technologies in Accounting, Vol. 13 No. 2, pp. 145168.

Bouten, L., \& Hoozée, S. (2013), "On the interplay between environmental reporting and management accounting change", Management Accounting Research, Vol. 24 No. 4, pp. 333-348.

Bouten, L., \& Hoozée, S. (2015), "Challenges in sustainability and integrated reporting", Issues in Accounting Education Teaching Notes, Vol. 30 No. 4, pp. 83-93.

Brennan, N., Guillamon-Saorin, E., \& Pierce, A. (2009), "Methodological Insights: Impression management: Developing and illustrating a scheme of analysis for narrative disclosures - a methodological note", Accounting, Auditing \& Accountability Journal, Vol. 22 No. 5, pp. 789-832. doi:doi:10.1108/09513570910966379

Brown, J., \& Dillard, J. (2014), "Integrated reporting: On the need for broadening out and opening up", Accounting, Auditing \& Accountability Journal, Vol. 27 No. 7, pp. 11201156.

Buitendag, N., Fortuin, G. S., \& de Laan, A. (2017), "Firm characteristics and excellence in integrated reporting", South African Journal of Economic and Management Sciences, Vol. 20 No. 1, pp. 1-8.

Carroll, A. B., \& Shabana, K. M. (2010), "The business case for corporate social responsibility: A review of concepts, research and practice", International journal of management reviews, Vol. 12 No. 1, pp. 85-105.

Chatterjee, B. (2008), "Highlights in annual reports: its perceived usefulness", International Journal of Commerce and Management, Vol. 17 No. 1/2, pp. 166-177. 
Chen, Y., Jermias, J., \& Nazari, J. A. (2016), "The Effects of CSR Reporting Frameworks and Financial Conditions on Managers' Willingness to Invest in CSR", SSRN. Retrieved from: https://papers.ssrn.com/sol3/papers.cfm?abstract id=2711053

Clatworthy, M., \& Jones, M. J. (2001), "The effect of thematic structure on the variability of annual report readability", Accounting, Auditing \& Accountability Journal, Vol. 14 No. 3, pp. 311-326.

Cook, M., \& Sutton, M. H. (1995), "Summary annual reporting: A cure for information overload", Financial Executive, Vol. 11 No. 1, pp. 12-15.

Coulson, A. B., Adams, C. A., Nugent, M. N., \& Haynes, K. (2015), "Exploring metaphors of capitals and the framing of multiple capitals: Challenges and opportunities for $<\mathrm{IR}>$ ", Sustainability Accounting, Management and Policy Journal, Vol. 6 No. 3, pp. 290-314.

Council on Higher Education (2009), Postgraduate Studies in South Africa: A Statistical Profile, Retrieved

from: http://www.che.ac.za/sites/default/files/publications/CHE MonitorProjectV7.pdf

Courtis, J. K. (1986), "An investigation into annual report readability and corporate risk-return relationships", Accounting and Business Research, Vol. 16 No. 64, pp. 285-294.

Courtis, J. K. (1995), "Readability of annual reports: Western versus Asian evidence", Accounting, Auditing \& Accountability Journal, Vol. 8 No. 2, pp. 4-17.

Courtis, J. K. (1998), "Annual report readability variability: tests of the obfuscation hypothesis", Accounting, Auditing \& Accountability Journal, Vol. 11 No. 4, pp. 459-472.

Courtis, J. K., \& Hassan, S. (2002), "Reading ease of bilingual annual reports", Journal of Business Communication, Vol. 39 No. 4, pp. 394-413.

De Klerk, M., \& De Villiers, C. (2012), "The value relevance of corporate responsibility reporting: South African evidence", Meditari Accountancy Research, Vol. 20 No. 1, pp. 21-38.

De Villiers, C., \& Alexander, D. (2014), "The institutionalisation of corporate social responsibility reporting", The British Accounting Review, Vol. 46 No. 2, pp. 198-212.

De Villiers, C., Rinaldi, L., \& Unerman, J. (2014), "Integrated Reporting: Insights, gaps and an agenda for future research", Accounting, Auditing \& Accountability Journal, Vol. 27 No. 7, pp. $1042-1067$.

De Villiers, C., Rouse, P., \& Kerr, J. (2016), "A new conceptual model of influences driving sustainability based on case evidence of the integration of corporate sustainability management control and reporting", Journal of Cleaner Production, Vol. 136 No., pp. 7885. 
De Villiers, C., \& Sharma, U. (2017), "A critical reflection on the future of financial, intellectual capital, sustainability and integrated reporting", Critical Perspectives on Accounting, Vol. No., pp. doi:https://doi.org/10.1016/i.cpa.2017.05.003

De Villiers, C., \& Van Staden, C. (2010a), "Shareholders' requirements for corporate environmental disclosures: A cross country comparison", The British Accounting Review, Vol. 42 No. 4, pp. 227-240.

De Villiers, C., \& van Staden, C. (2010b), "Why do shareholders' require corporate environmental disclosure?", South African Journal of Economic and Management Sciences, Vol. 13 No., pp. 437-446.

De Villiers, C., \& Van Staden, C. J. (2006), "Can less environmental disclosure have a legitimising effect? Evidence from Africa", Accounting, Organizations and Society, Vol. 31 No. 8, pp. 763-781.

De Villiers, C., Venter, E. R., \& Hsiao, P. C. K. (2016), "Integrated reporting: background, measurement issues, approaches and an agenda for future research", Accounting \& Finance, Vol. No., pp.

Deegan, C. (2000), "Firms' disclosure reactions to major social incidents: Australian evidence", Accounting Forum, Vol. 24 No. 1, pp. 101-130.

Deegan, C., \& Rankin, M. (1997), "The materiality of environmental information to users of annual reports", Accounting, Auditing \& Accountability Journal, Vol. 10 No. 4, pp. 562583.

Dreyer, L. G. (1984), "Readability and responsibility", Journal of Reading, Vol. 27 No. 4, pp. 334-338.

Eccles, R., \& Armbrester, K. (2011), "Integrated reporting in the cloud", IESE Insight, Vol. 8 No. 1, pp. 13-20.

Eccles, R., loannou, I., \& Serafeim, G. (2014), "The impact of corporate sustainability on organizational processes and performance", Management Science, Vol. 60 No. 11, pp. 2835-2857.

Eccles, R., \& Saltzman, D. (2011), "Achieving sustainability through integrated reporting", Stanf Soc Innov Rev Summer, Vol. 59 No., pp.

Eccles, R., Serafeim, G., \& Krzus, M. (2011), "Market interest in nonfinancial information", Journal of Applied Corporate Finance, Vol. 23 No. 4, pp. 113-127.

Ernst \& Young (2012), Ernst \& Young's Excellence in Integrated Reporting Awards 2012: A survey of integrated reports from South Africa's top 100 companies and Top 10 stateowned entities, Retrieved from: http://www.ey.com/Publication/vwLUAssets/EY- 
excellence-in-integrated-reporting-awards-2012/\$FILE/EY-excellence-in-integratedreporting-awards-2012.pdf

Esterhuyse, L., \& Wingard, C. (2016), "An exploration of the online investor relations (IR) practices of companies listed on the Johannesburg Stock Exchange (JSE)", South African Journal of Economic and Management Sciences, Vol. 19 No. 2, pp. 215-231.

Eugene Baker III, H., \& Kare, D. D. (1992), "Relationship between annual report readability and corporate financial performance", Management Research News, Vol. 15 No. 1, pp. 1-4.

Firtel, K. B. (1998), "Plain English: A reappraisal of the intended audience of disclosure under the Securities Act of 1933", S. Cal. L. Rev., Vol. 72 No., pp. 851.

Flesch, R. (1948), "A new readability yardstick", Journal of applied psychology, Vol. 32 No. 3, pp. 221.

Flesch, R. (1979, 26 June 2017), "How to write plain English: Let's start with the formula", Retrieved from: http://www.mang.canterbury.ac.nz/writing guide/writing/flesch.shtml

Flower, J. (2015), "The international integrated reporting council: a story of failure", Critical Perspectives on Accounting, Vol. 27 No., pp. 1-17.

Gunning, R. (1969), "The fog index after twenty years", Journal of Business Communication, Vol. 6 No. 2, pp. 3-13.

Higgins, C., Stubbs, W., \& Love, T. (2014), "Walking the talk (s): Organisational narratives of integrated reporting", Accounting, Auditing \& Accountability Journal, Vol. 27 No. 7, pp. 1090-1119.

Hooghiemstra, R. (2000), "Corporate communication and impression management-new perspectives why companies engage in corporate social reporting", Journal of Business Ethics, Vol. 27 No. 1, pp. 55-68.

Hrasky, S., \& Smith, B. (2008), "Concise corporate reporting: communication or symbolism?", Corporate Communications: An International Journal, Vol. 13 No. 4, pp. 418-432.

Hutton, A. (2004), "Beyond financial reporting an integrated approach to disclosure", Journal of Applied Corporate Finance, Vol. 16 No. 4, pp. 8-16.

IIRC (2013), The International Integrated Reporting Framework Retrieved from:

loana, D., \& Adriana, T.-T. (2014), "Research agenda on integrated reporting: new emergent theory and practice", Procedia Economics and Finance, Vol. 15 No., pp. 221-227.

IoDSA (2009), King Report on Corporate Governance for South Africa (King III), Institute of Directors, Johannesburg. 
IoDSA (2016), King IV report on coproate governance for South Africa, Retrieved from: http://c.ymcdn.com/sites/www.iodsa.co.za/resource/resmgr/king iv/King IV Report/loD SA King IV Report - WebVe.pdf

IRCSA (2011), Framework for integrated reporting and the integrated report - a discussion paper, Retrieved from:

Jones, M. J. (1988), "A longitudinal study of the readability of the chairman's narratives in the corporate reports of a UK company", Accounting and Business Research, Vol. 18 No. 72, pp. 297-305.

Jones, M. J. (1996), "Readability of annual reports: Western versus Asian evidence-a comment to contexualize", Accounting, Auditing \& Accountability Journal, Vol. 9 No. 2, pp. 86-91.

Jones, M. J., \& Shoemaker, P. A. (1994), "Accounting narratives: A review of empirical studies of content and readability", Journal of Accounting Literature, Vol. 13 No., pp. 142.

JSE (2013), JSE Limited Listings Requirements, Retrieved from: https://www.jse.co.za/content/JSERulesPoliciesandRegulationltems/JSE\%20Listings\%2 ORequirements.pdf

Kim, S., Maas, K., \& Perego, P. (2017), "The Effect of Publication, Format and Content of Integrated Reports on Analysts' Earnings Forecasts", SSRN. Retrieved from: https://papers.ssrn.com/sol3/papers.cfm?abstract id=2902549

Kincaid, J., Aagard, J., O' Hara, J., \& Cottrell, L. (1981), "Computer readability editing system", IEEE Transactions on Professional Communication, Vol. PC-24 No. 1, pp. 38-42. doi:10.1109/TPC.1981.6447821

Kincaid, J., Fishburne Jr, R., Rogers, R., \& Chissom, B. (1975), Derivation of new readability formulas (automated readability index, fog count and flesch reading ease formula) for navy enlisted personnel, Retrieved from: http://oai.dtic.mil/oai/oai?verb=getRecord\&metadataPrefix=html\&identifier=ADA006655

Klare, G. R. (1974), "Assessing readability", Reading research quarterly, Vol. No., pp. 62-102.

Krzus, M. (2011a), "The Case for Integrated Reporting". In R. Schatz \& L. Watson (Eds.), Trust Meltdown II: The financial industry needs a fundamental restart (pp. 82-88), Innovatio, Place published.

Krzus, M. (2011b), "Integrated reporting: if not now, when?", Zeitschrift fuer Internationale Rechnungslegung, Vol. 6 No., pp. 271-276.

Lai, A., Melloni, G., \& Stacchezzini, R. (2014), "Corporate sustainable development: is 'integrated reporting'a legitimation strategy?", Business Strategy and the Environment, Vol. 25 No. 3, pp. 12. 
Lambooy, T., Hordijk, R., \& Bijveld, W. (2014), "Communicating about Integrating Sustainability in Corporate Strategy: Motivations and Regulatory Environments of Integrated Reporting from a European and Dutch Perspective", Critical Studies on Corporate Responsibility, Governance and Sustainability, Vol. 6 No., pp. 217-255.

Lehavy, R., Li, F., \& Merkley, K. (2011), "The Effect of Annual Report Readability on Analyst Following and the Properties of Their Earnings Forecasts", The Accounting Review, Vol. 86 No. 3, pp. 1087-1115.

Li, F. (2008), "Annual report readability, current earnings, and earnings persistence", Journal of Accounting and Economics, Vol. 45 No. 2, pp. 221-247.

Linsley, P. M., \& Lawrence, M. J. (2007), "Risk reporting by the largest UK companies: readability and lack of obfuscation", Accounting, Auditing \& Accountability Journal, Vol. 20 No. 4 , pp. 620-627.

Lo, K., Ramos, F., \& Rogo, R. (2017), "Earnings management and annual report readability", Journal of Accounting and Economics, Vol. 63 No. 1, pp. 1-25.

Maas, K., Schaltegger, S., \& Crutzen, N. (2016), "Reprint of Advancing the integration of corporate sustainability measurement, management and reporting", Journal of Cleaner Production, Vol. 136 No., pp. 1-4.

Magnaghi, E., \& Aprile, R. (2014), "Integrated Reporting: A Theoretical Perspective on This Critical Issue", Journal of Business and Economics, Vol. 5 No. 8, pp. 1320-1337.

Maroun, W. (2015), "Culture, profitability, non-financial reporting and a meta-analysis: Comments and observations", Meditari Accountancy Research, Vol. 23 No. 3, pp. 322330.

Maroun, W., Coldwell, D., \& Segal, M. (2014), "SOX and the transition from apartheid to democracy: South African auditing developments through the lens of modernity theory", International Journal of Auditing, Vol. 18 No. 3, pp. 206-212.

Melloni, G., Caglio, A., \& Perego, P. (2017), "Saying more with less? Disclosure conciseness, completeness and balance in Integrated Reports", Journal of Accounting and Public Policy, Vol. No., pp.

Milne, M. J., \& Gray, R. (2013), "W (h) ither ecology? The triple bottom line, the global reporting initiative, and corporate sustainability reporting", Journal of Business Ethics, Vol. 118 No. 1, pp. 13-29.

Montecchia, A., Giordano, F., \& Grieco, C. (2016), "Communicating CSR: integrated approach or selfie? Evidence from the Milan Stock Exchange", Journal of Cleaner Production, Vol. 136 No., pp. 42-52. 
Morton, J. R. (1974), "Qualitative objectives of financial accounting: a comment on relevance and understandability", Journal of Accounting Research, Vol. No., pp. 288-298.

Neu, D., Warsame, H., \& Pedwell, K. (1998), "Managing public impressions: environmental disclosures in annual reports", Accounting, Organizations and Society, Vol. 23 No. 3, pp. 265-282.

Parker, L. (1982), "Corporate annual reporting: a mass communication perspective", Accounting and Business Research, Vol. 12 No. 48, pp. 279-286.

Pashalian, S., \& Crissy, W. J. (1952), "Corporate annual reports are difficult, dull reading, human interest value low, survey shows", Journal of Accountancy (pre-1986), Vol. 94 No. 000002, pp. 215.

Patten, D. M. (1991), "Exposure, legitimacy, and social disclosure", Journal of Accounting and Public Policy, Vol. 10 No. 4, pp. 297-308.

Patten, D. M. (1992), "Intra-industry environmental disclosures in response to the Alaskan oil spill: a note on legitimacy theory", Accounting, Organizations and Society, Vol. 17 No. 5, pp. 471-475.

Phillips, D., Watson, L., \& Willis, M. (2011), "Benefits of comprehensive integrated reporting: by standardizing disparate information sources, financial executive can eliminate the narrow perspectives of the elephant and the blind man parable--and" see" beyond merely information silos or reports", Financial Executive, Vol. 27 No. 2, pp. 26-31.

Rahman, A. A. (2014), "A Longitudinal Study of the Readability of the Chairman's Narratives in Corporate Reports: Malaysian Evidence", World Academy of Science, Engineering and Technology, International Journal of Social, Behavioral, Educational, Economic, Business and Industrial Engineering, Vol. 8 No. 7, pp. 2044-2051.

Rensburg, R., \& Botha, E. (2014), "Is Integrated Reporting the silver bullet of financial communication? A stakeholder perspective from South Africa", Public Relations Review, Vol. 40 No. 2, pp. 144-152.

Richards, G., \& van Staden, C. (2015), "The readability impact of international financial reporting standards", Pacific Accounting Review, Vol. 27 No. 3, pp. 282-303.

Roberts, L. (2011), "Integrated reporting: the status quo", Accountancy SA, Vol. No., pp. 11-12.

Rossouw, G., \& West, A. (2009), "The ethics of corporate governance: A (South) African perspective", International Journal of Law and Management, Vol. 51 No. 1, pp. 10-16.

Rutherford, B. A. (2002), "The production of narrative accounting statements: an exploratory study of the operating and financial review", Journal of Applied Accounting Research, Vol. 6 No. 3, pp. 25-56. 
Sattari, S., Pitt, L. F., \& Caruana, A. (2011), "How readable are mission statements? An exploratory study", Corporate Communications: An International Journal, Vol. 16 No. 4, pp. 282-292.

Schroeder, N., \& Gibson, C. (1992), "Are summary annual reports successful?", Accounting Horizons, Vol. 6 No. 2, pp. 28.

Setia, N., Abhayawansa, S., Joshi, M., \& Huynh, A. V. (2015), "Integrated reporting in South Africa: some initial evidence", Sustainability Accounting, Management and Policy Journal, Vol. 6 No. 3, pp. 397-424.

Slack, R., \& Tsalavoutas, I. (2017), "Equity market diffusion and resistance to Integrated Reporting", Vol. No., pp.

Smeuninx, N., De Clerck, B., \& Aerts, W. (2016), "Measuring the Readability of Sustainability Reports A Corpus-Based Analysis Through Standard Formulae and NLP", International Journal of Business Communication, Vol. No., pp. 1-34. doi:10.1177/2329488416675456

Smith, J., \& Smith, N. (1971), "Readability: A measure of the performance of the communication function of financial reporting", The Accounting Review, Vol. 46 No. 3, pp. 552-561.

Smith, M., \& Taffler, R. (1992), "Readability and understandability: Different measures of the textual complexity of accounting narrative", Accounting, Auditing \& Accountability Journal, Vol. 5 No. 4, pp.

Solomon, J., \& Maroun, W. (2012), "Integrated reporting: the influence of King III on social, ethical and environmental reporting", Vol. No. 30 June 2017, pp.

Soper, F. J., \& Dolphin, R. (1964), "Readability and corporate annual reports", The Accounting Review, Vol. 39 No. 2, pp. 358-362.

Stacchezzini, R., Melloni, G., \& Lai, A. (2016), "Sustainability management and reporting: the role of integrated reporting for communicating corporate sustainability management", Journal of Cleaner Production, Vol. 136 No., pp. 102-110.

Stanton, P., Stanton, J., \& Pires, G. (2004), "Impressions of an annual report: an experimental study", Corporate Communications: An International Journal, Vol. 9 No. 1, pp. 57-69.

Statistics South Africa (2017), Education series volume III: Educational Enrolment and Achievement, 2016, Retrieved from:

Stevens, K. T., Stevens, K. C., \& Stevens, W. P. (1992), "Measuring the readability of business writing: The cloze procedure versus readability formulas", Journal of Business Communication, Vol. 29 No. 4, pp. 367-382. 
Steyn, M. (2014), "Organisational benefits and implementation challenges of mandatory integrated reporting: Perspectives of senior executives at South African listed companies", Sustainability Accounting, Management and Policy Journal, Vol. 5 No. 4, pp. 476-503.

Stubbs, W., \& Higgins, C. (2014), "Integrated reporting and internal mechanisms of change", Accounting, Auditing \& Accountability Journal, Vol. 27 No. 7, pp. 1068-1089.

Subramanian, R., Insley, R. G., \& Blackwell, R. D. (1993), "Performance and readability: A comparison of annual reports of profitable and unprofitable corporations", Journal of Business Communication, Vol. 30 No. 1, pp. 49-61.

Sydserff, R., \& Weetman, P. (1999), "A texture index for evaluating accounting narratives: An alternative to readability formulas", Accounting, Auditing \& Accountability Journal, Vol. 12 No. 4, pp. 459-488.

Thomas, J. (1997), "Discourse in the marketplace: The making of meaning in annual reports", The Journal of Business Communication (1973), Vol. 34 No. 1, pp. 47-66.

Tilt, C. A. (2006), "Linking environmental activity and environmental disclosure in an organisational change framework", Journal of Accounting \& Organizational Change, Vol. 2 No. 1, pp. 4-24.

Van Bommel, K. (2014), "Towards a legitimate compromise? An exploration of integrated reporting in the Netherlands", Accounting, Auditing \& Accountability Journal, Vol. 27 No. 7, pp. 1157-1189.

Vourvachis, P., Woodward, T., Woodward, D. G., \& Patten, D. M. (2016), "CSR disclosure in response to major airline accidents: a legitimacy-based exploration", Sustainability Accounting, Management and Policy Journal, Vol. 7 No. 1, pp. 26-43.

Wee, M., Tarca, A., Krug, L., Aerts, W., Pink, P., \& Tilling, M. (2016), Factors Affecting Preparers' and Auditors' Judgements about Materiality and Conciseness in Integrated Reporting, ACCA, London.

West, A. (2006), "Theorising South Africa's corporate governance", Journal of Business Ethics, Vol. 68 No. 4, pp. 433-448.

West, A. (2009), "The ethics of corporate governance: A (South) African perspective", International Journal of Law and Management, Vol. 51 No. 1, pp. 10-16.

Wild, S., \& van Staden, C. (2013), "Integrated reporting: initial analysis of early reporters-an institutional theory approach", paper presented at the 7th Asia Pacific Interdisciplinary Accounting Research Conference. 
Williams, S. J., \& Adams, C. A. (2013), "Moral accounting? Employee disclosures from a stakeholder accountability perspective", Accounting, Auditing \& Accountability Journal, Vol. 26 No. 3, pp. 449-495.

Wilmshurst, T. D., \& Frost, G. R. (2000), "Corporate environmental reporting: a test of legitimacy theory", Accounting, Auditing \& Accountability Journal, Vol. 13 No. 1, pp. 10-26.

Zhou, S., Simnett, R., \& Green, W. (2017), "Does integrated reporting matter to the capital market?", Abacus, Vol. 53 No. 1, pp. 94-132. 